\title{
Accumulation of biomedical waste due to COVID- 19: Concerns and strategies for effective treatment to control the pandemic
}

\section{Pon Pavithiran}

Vellore Institute of Technology: VIT University

\section{Arpit Bhatia}

Vellore Institute of Technology: VIT University

\section{Anmol Verma}

Vellore Institute of Technology: VIT University

\section{Nehal Ratnesh Shah}

Vellore Institute of Technology: VIT University

Prakash Pratyush

Vellore Institute of Technology: VIT University

\section{Vigneswaran Shanmugarajan}

Saveetha University - Poonamallee Campus: Saveetha University

\section{Sung Chul Kim}

Yeungnam University

GaneshKumar Poongavanam ( $\nabla$ selgan.cad@gmail.com )

Yeungnam University https://orcid.org/0000-0003-3971-2454

\section{Sakthivadivel Duraiswamy}

Vellore Institute of Technology: VIT University

\section{Research Article}

Keywords: Incineration, SARS-Cov-2 virus, Face mask, biomedical waste management.

Posted Date: January 18th, 2022

DOI: https://doi.org/10.21203/rs.3.rs-1136646/v1

License: (c) (i) This work is licensed under a Creative Commons Attribution 4.0 International License.

Read Full License 


\section{Abstract}

This research paper deals with the pollution impact of biomedical waste (BMW) generation due to the COVID-19 pandemic, at both global and national levels. This discussion is important in the light of clear scientific evidence that apart from the airborne transmission of the disease, the virus also survives on different surfaces carrying with it the risk of infection. Moreover, an investigation is conducted on the generation of biomedical waste in tons/day in India during the COVID period and future projections are also made. In addition, a pioneering study has been carried out to estimate the usage of facemasks in the context of the COVID-19 pandemic in India. This paper also provides a feasible solution by adopting a modern perspective towards the handling of BMW generated in the context of the SARS-Cov-2 virus at isolation wards and crematoriums. Stratagem approaches are suggested for the segregation and safe disposal of BMW. The latest availability of disposal facilities has been discussed based on the source data provided by the Central Pollution Control Board (CPCB). Even though a variety of disposal mechanisms are currently being followed in India, deliberations are made with Quantitative and Qualitative disposal deploying the popular incineration technology. The impact of the existing incineration technology on the environment and human health is extensively studied. The study is concluded with the suggestions of an effective measure to control the generation of BMW during the COVID-19 pandemic.

\section{Introduction}

The waste generated in the course of the medical diagnosis, treatment, and research activities is considered Biomedical waste (BMW). The proper handling of these BMWs is critical and continues to remain a highly challenging problem over the past few decades. As per the World Health Organization (WHO), the total amount of general and non-hazardous waste generated by healthcare activities is about $85 \%$ while the remaining $15 \%$ includes clinical solid waste, expired vaccines, unlabelled products, medical instruments, and organic fluids which are considered as infectious, toxic and hazardous to humans and the environment (WHO, 2018). Due care and caution must therefore be taken to ensure that these wastes are properly handled and segregated safely. To manage the large portion of these wastes by healthcare institutions, numerous technologies are in practice all around the globe such as sewage, land disposal, gasification, incineration, etc. Best Available Technology (BAT) survey for identifying safe and sustainable biomedical waste treatment options and management methodologies was conducted for 24 countries of the Western Pacific area in 2012. It was found that Japan and the Republic of South Korea were the only two countries that effectively managed their biomedical wastes. The evaluation was done by assessing five major areas of management, i.e. training, policy and regulatory framework, technologies implemented, and financial resources (Datta et al., 2018). Canada is one of the pioneers in the field as it has centralized provincial facilities for BMW sterilization (Walkinshaw, 2011).

Several decades ago, not much importance was given to biomedical waste and Indian scavengers working in recycling stations were found to be unequipped with protective equipment. For instance, medical syringes were reused without proper sterilization until 2009 (Salkin, 2004). During this period, 
around 240 people in Gujarat were affected with Hepatitis B due to the reuse of unsterilized syringes (Seetharam, 2009). International clinical epidemiology imposed the existing BMW practices in 20 states of India during 2002-2004 based on detailed questionnaires used to sub-classify its standards. An earlier research study found that $82 \%, 60 \%$, and $54.2 \%$ of primary, secondary, and tertiary healthcare centres, respectively, were in the red category indicating the critical need for immediate measures to stringently enforce an efficient BMW management system in the country to curb the spread of infections (Arora et al., 2014).

The generation of BMW has increased at an abnormal rate over the recent past due to the spread of the coronavirus disease "COVID-19", an infectious virus whose origin has been traced to a localized seafood marketplace in Wuhan, China; it was later referred as "SARS-CoV-2" by WHO on January 12, 2020 (Dharmaraj et al., 2021). Due to the global transmission and worldwide impact of the coronavirus, WHO further declared this as a pandemic on March 11,2020. As per the reports published till 16th September 2021, SARS-CoV-2 have spreading across 237 republics with 22,62,36,577 confirmed cases including $46,54,548$ deaths as of the date (WHO, 2021b). The increasing rate of COVID-19 is greater than SARS and MERS with a short gestation time of 24 hours (Zhang et al., 2020). The primary source of transmission of COVID-19 is through inhalation of respiratory droplets from close contact with an infected person (Kitajima et al., 2020). Several research studies reveal that COVID-19 can also be transmitted in other ways, it is shed in the faces of infected patients displaying acute symptoms, it can be contracted from asymptomatic persons, and patients treated without any signs (Thakur et al., 2021).

This situation has resulted in many healthy people getting infected, needed medical treatment, and in certain severe cases requiring hospital admission. The essential protective equipment used by healthcare professionals for treating the sick and the mandatory precautionary safety measures like facial masks and hand gloves has led to a stupendous increase in the accumulation of BMW all around the world. In China, nearly 240 tons of medical waste were disposed of per day during the pandemic compared to a mere 40 tonnes on normal days (Hossain et al., 2020). In India, even before the pandemic, the generation of BMW had increased from 559 tonnes per day to 613 tonnes (CSE India, 2021) and in the course of battling the pandemic, the country currently generating BMW of around 850 tonnes/day (Chand et al., 2021). The major repercussion of this steadily increasing BMW generation is the effect on the environment. Thousands of sanitation workers, rag pickers, and waste segregation having no proper awareness of the need for personal protective systems leading to the loss of many precious human lives.

The generation of BMW at the end of COVID's first and second waves was still on an increasing trend due to the careless disposal of surgical masks, gloves, personal protective equipment suits, etc., leading to many people getting affected by the SARS-Cov-2. The Indian government has recommended that all healthy people of age 18 and above must get their vaccination and as of 14th September 2021 $5,63,45,33,040$ people have been successfully vaccinated (WHO, 2021a). The syringes and the vials used in the course of the vaccination drive have added to the increasing pile of BMW. To manage the enormous amount of waste produced on a day-to-day basis during the pandemic, a proper BMW disposal method has to be adopted. Although the government of India has imposed stringent rules, regulations 
and specified guidelines for maintaining a clean ecosystem without the deployment of appropriate technological solutions these regulatory policies are largely ineffective in an available for safe disposal of BMW but a majority of Indian states have adopted the incineration technique due to the advantages of the requirement of less area, energy and cost.

In this context, to help society and to address the identified information gap, the key objective of this assessment study is to produce the current knowledge on approaches for treating BMW generated, to support further research needs, and resolve the obstructions to the enactment of various treatment technologies. The impact of the coronavirus on the BMW generation is deliberated in detail to existing a crystal pure image to the scientific society. Various remedial approaches for efficient BMW management are discussed along with their advantages and disadvantages. In the light of the increasing number of COVID-19 cases and the danger of an impending catastrophe of the third wave from new variants and mutations of the virus, the creation of greater awareness can help in drawing the attention of the scientific community and society to the critical need for effective BMW management in India.

\section{Persistence Of Coronavirus Variants On Different Surfaces}

Early clinical research records indicated, the possibility of the virus spreading through zoonotic transmission. Subsequent reanalysis of the epidemic data showcased that it was spread via human-tohuman transmission in December 2019 (Nishiura et al., 2020). The mode of transmission of the coronavirus is through respiratory droplets from the sneeze or cough of an infected person which lingers over some time on different surfaces (Suman et al., 2020), this is called an infection decay. Figure 1 depicts the decay time of the SARS Cov-2 virus for different materials most of which are commonly part of BMW. Alcohol-based disinfectants called sanitizers can significantly reduce the survival and decay time of different variants of the coronavirus (Gold \& Avva, 2018).

\section{Potential Generation Of Bmw From Leading Covid-19 Cases}

The present article discusses the global situation as well as the Indian scenario of the impact the SARSCoV-2 virus has on biomedical waste generation and suggests measures for its effective management through various strategies using systematic approaches. In addition, it covers the possibility of BMW leading to more COVID-19 cases, current perspectives of BMW management, ongoing biomedical waste management strategies, global behavior patterns in waste collection and disposal, challenges in handling BMW management, environmental effects, and potential strategies of sustainability. Figure 2 illustrates a sequential overview of healthcare solid waste management during the COVID-19 pandemic.

\subsection{Global Scenario}

The impact of COVID-19 has increased the global market for Personal Protective Equipment (PPE) from $\$ 40$ billion to $\$ 58$ billion. The BMW produced in different countries (tons/day) is projected in Figure 3 . The collection and disposal of BMW between 22nd March and 12th April 2020 in the capital city of 
Regina in Canada were noted to have increased nearly fourfold from 355.5 to 1222.4 tons per week (Richter et al., 2021). Similarly, the State Council of China found that approximately 468.9 tons of medical waste were produced every day (Peng et al., 2020). In Indonesia, it was noted that the produced medical waste reached 12740 tons in the first 60 days from the 1 st case of COVID-19. Sangkham (2020) studied the total generation of medical waste by all the countries and identified that the highest quantities of medical waste were produced by India, Iran, Pakistan, Saudi Arabia, Bangladesh, and Turkey (Sangkham, 2020).

\subsection{Indian Scenario}

Due to the increase in the number of treatment centers during the initial period of the pandemic, there was a corresponding increase in the generation of BMW. The Central Pollution Control Board (CPCB) estimated that India produced 710 metric tons (MT) of BMW per day, as of May 31st 2020. Around 101 $\mathrm{MT} /$ day of the projected amount was from COVID treatment hospitals, quarantine wards, sample collection centers, and testing laboratories. The total BMW produced by private and government hospitals before the pandemic was $500 \mathrm{grams} / \mathrm{bed} / \mathrm{day}$. This figure shot up $2.5-4 \mathrm{~kg} / \mathrm{day} / \mathrm{bed}$ (Singh, 2020) after the impact of COVID. The meticulous segregation of BMW based on the intensity of patient infection is one of the best ways to restrict further COVID-19 cases. Fig. 4 depicts the data on the generation of BMW (CPCB, 2021) and the increasing case history in India (WHO, 2021b) which infers the rate of change in BMW generation depends on the number of COVID cases in India.

\subsubsection{Indian-States Scenario}

The entire nation has focussed all its efforts in battling against the COVID-19 pandemic situation with many people struggling to earn enough for their basic livelihood. All citizens have started taking precautionary measures such as using masks, PPE kits, shields, gloves, taking the vaccine, maintaining social distancing, and self-quarantining when ill. The СРСB has released the State-wise BMW details, as shown in Fig. 5.

Due to a market increase in the usage of single-use medical/clinical protective wear as precautionary measures, there has been a substantial increment in the quantum of BMW generated on a day-to-day basis.

\section{Estimation Of Usage Of Face Masks In India During The Covid-19 Pandemic.}

The discarded wastes of masks and gloves contaminated with blood, bodily fluids, tissues, organs, and sharp objects from the clinical treatment are known as BMW. If handled and disposed of without care, they are likely to pollute the environment and cause health issues. Everyone has started using the face mask as a precautionary measure against the coronavirus, particularly after a Governmental advisory about its importance. To develop an efficient waste management system during this pandemic, the estimation of the face mask usage in different states of India was projected in an earlier research study. 
The information regarding the confirmed COVID-19 cases in India was collected from the official website of myGovIndia and the population statics were collected from uidai. The quantity of daily facemask usage was estimated using the following equation (1):

$D_{n}=P \times U_{p} \times F_{R} \times F_{d}(1)$

This study provides a reliable forecast of the country's usage of face masks during the COVID-19 pandemic. From Fig. 6 it is seen that it was forecasted that 32,39,80,624 face masks would be used in India (Sangkham, 2020). From the graph, it is inferred that the rate of increase in usage of masks depends on the number of COVID patients affected in the respective states. Maharashtra, Uttar Pradesh, Tamil Nadu, and West Bengal were the three Indian states observed to be top of the table with the highest number of COVID cases.

\section{Modern Bmw Management In The Context Of Sars-cov-2 Virus}

A steady increase in the number of people who are sick after being infected with the coronavirus is being witnessed and has affected the living standards of people all around the globe. To bring the rampant spread of infection under control, India has refurbished 238170 healthcare centres out of which 87267 are equipped with BMW separation (Chand et al., 2021) techniques. The CPCB has revised the recommendations for treatment, handling and dumping of BMW produced for the duration of the diagnosis/isolation/treatment of COVID-19 patients (CPCB, 2020) based on the specific segregation and disposal facilities that were drafted under BMW Management Rules, 2016.

\subsection{Handling of waste from COVID-19 isolation wards.}

The following are some of the BMW handling processes followed in corona wards in India:-.

- Separate color bins with foot-operated lids to maintain proper waste segregation.

- Use of double-layered bags for the collection of BMW.

- Collection and storage of BMW before handing it over to the concerned staff of Common Biomedical Waste Treatment Facilities (CBMWTF).

- Labeling the segregated COVID-19 BMW bags as "COVID-19 Waste".

- Use of dedicated trolley and bins, treated with disinfectant after every use.

- The feces of COVID-19 patients are to be treated as BMW and to be collected in a diaper before disposal in the yellow bag.

\subsection{Handling and Disposal of used PPEs}

- Waste masks and gloves should be kept in a yellow bag for a minimum of 72 hours before disposal to avoid the risk of virus transmission. 
- Discarded PPE from the general public should be stored in a separate bin for 3 days, before their disposal as dry general solid waste after shredding.

- At material recovery facilities, discarded PPEs containing plastic should be shredded and sent to authorized plastic waste recyclers or converted into refuse-derived fuel (RDF) for co-processing or energy recovery in road-making.

\subsection{Handling of BMW in crematoriums}

The rapid spread of the COVID-19 virus all over the world has resulted in 4654548 deaths at a global level with 443928 in India as of $16^{\text {th }}$ September 2021 (Worldometer, 2021). There are no restrictions on the disposal of the incineration ash which remains after the cremation of the dead bodies of corona (WHO, 2020a). But regulations have been laid down for the BMW that accumulates at the crematorium. Higher leeway for the transmission of the coronavirus can be checked and controlled by proper handling and management of the generated BMW. The BMW generated in the crematorium has to be collected in a separate bin with a yellow bag, it must be left untouched for 72 hours, and then handed over to authorized waste pickers. The waste must then be disposed of as per the provisions given under sewage waste management rules, 2016 and BMW Management Rules, 2016.

\subsection{Guidelines for Handling Facial Mask}

According to the guidelines given by the All India Institutes of Medical Sciences (AlIMS), N95 masks should be decontaminated with $11 \%$ hydrogen peroxide vapours (HPV) whereas $70 \%$ ethanol and $0.5 \%$ sodium hypochlorite solution should be used to decontaminate the face shields and goggles. Based on the results of HPV treatment formulated by Fischer et al. (2020), it was noted that this method exhibits the best results in rapid inactivation of SARS-CoV-2. In addition, dry heating at $70{ }^{\circ} \mathrm{C}$ can kill the virus. Decontamination with alcohol can degrade the integrity of the N95 mask and is hence not recommended. The study suggested that the respirators can be decontaminated a maximum of three times by UV and HPV treatments, and two times by dry heat (Fischer et al., 2020).

\section{Potential Bmw Management Strategies During Covid-19 Pandemic}

Due care and caution must be exercised in the disposal of BMW as they needed to be collected as per the governmental regulations and medical care facility (MCF) rules. Many countries have adopted the best possible waste management strategies based on their available resources, capacity, and commitment.

\subsection{Segregation of Biomedical waste}

The healthcare solid waste classification criteria set by WHO covers the separation of different types of waste according to the classification after its immediate usage. Segregation involves the separation of waste into appropriate containers with color codes, as shown in Figure 7. Color-coding is employed to identify the different types of waste easily. Red bins are commonly used to dispose of infectious waste. General healthcare waste is placed in black bins, yellow bins are used for sharp wastes, and blue bins for 
solid type wastes. These waste containers should be rigid, leak-proof, unbreakable, and Punctureresistant (Das et al., 2021).

\subsection{Various disposal practices of BMW management}

Clinical biomedical wastes are classified into general waste and perilous waste. The general waste does not require any extra care, whereas perilous waste must be handled carefully during its disposal. The commonly used methods of disposal are in drains, land disposal, plasma gasification, and incineration. Table 1 shows the disposal methods of the generated biomedical waste. Some of these methods are suitable for use within the premises of the healthcare facilities (Reddy et al., 2021, Tagorti and Kaya, 2021

). The sterilization can be done in a small area allocated specially for BMW in hospitals, as depicted in Table 2.

Table1. Comparison of different methods for disposable of BMW

\begin{tabular}{|c|c|c|c|c|}
\hline Parameters & Sewage/Drain & Land Disposal & Plasma Gasification & Incineration \\
\hline Availability & $\begin{array}{l}\text { Common and } \\
\text { assessable }\end{array}$ & $\begin{array}{l}\text { Common and } \\
\text { oldest }\end{array}$ & $\begin{array}{l}\text { Difficult due to } \\
\text { technical } \\
\text { impracticalities }\end{array}$ & Cheap and affordable \\
\hline Cost & Moderate & Low & High & Efficient \\
\hline $\begin{array}{l}\text { Feed for } \\
\text { treatment }\end{array}$ & $\begin{array}{l}\text { Liquid } \\
\text { Biomedical } \\
\text { waste }\end{array}$ & $\begin{array}{l}\text { Biomedical } \\
\text { waste }\end{array}$ & $\begin{array}{l}\text { Municipal, solid, } \\
\text { biomedical, and } \\
\text { hazardous wastes }\end{array}$ & $\begin{array}{l}\text { All types of wastes apart } \\
\text { from sharp items }\end{array}$ \\
\hline $\begin{array}{l}\text { Need for } \\
\text { pre- } \\
\text { treatment }\end{array}$ & Yes & No & No & No \\
\hline $\begin{array}{l}\text { Types of } \\
\text { Pollution } \\
\text { contributed }\end{array}$ & $\begin{array}{l}\text { Water } \\
\text { contamination } \\
\text { and } \mathrm{GHG}\end{array}$ & $\begin{array}{l}\text { Air pollution, } \\
\text { and water } \\
\text { contamination }\end{array}$ & Air pollution & Air pollution \\
\hline By-product & $\begin{array}{l}\text { Semi-solid } \\
\text { waste or } \\
\text { Slurry }\end{array}$ & $\begin{array}{l}\text { Ash when } \\
\text { burned }\end{array}$ & $\begin{array}{l}\text { Slag and reduced } \\
\text { metals, Producer } \\
\text { Gas }\end{array}$ & $\begin{array}{l}\text { Incineration ash (another } \\
\text { type of biomedical waste), } \\
\text { Heavy metals }\end{array}$ \\
\hline
\end{tabular}


Table 2

Different sterilization techniques for killing germs/pathogens

\begin{tabular}{|ll|}
\hline Autoclaving & $\begin{array}{l}\text { Low-heat warm cycle wherein steam is carried into direct contact with } \\
\text { biomedical squander to sterilize the waste. }\end{array}$ \\
\hline Microwave Light & $\begin{array}{l}\text { The warm impact of electromagnetic radiation ranges between the frequencies } \\
\text { of } 300 \text { and } 300,000 \mathrm{MHz} \text { results in microbial inactivation. }\end{array}$ \\
\hline $\begin{array}{l}\text { Low warmth } \\
\text { treatment } \\
\text { frameworks }\end{array}$ & This innovative treatment purifies squander by destroying microorganisms. \\
$\begin{array}{l}\text { Synthetic } \\
\text { Techniques }\end{array}$ & $\begin{array}{l}\text { Utilized regularly in medical care to kill microorganisms on clinical gear and all } \\
\text { floors and dividers }\end{array}$ \\
\hline
\end{tabular}

\subsection{Indian Waste Management Scenario}

As per the information given by the State Pollution Control Boards (SPCBs), $101 \mathrm{~T} / \mathrm{d}$ of COVID-19 BMW was produced from 2907 hospitals, 20707 quarantine centres, 1539 sample collection centres, and 264 testing laboratories in the year 2020. The overall capacity of all the treatment plants in India was $710 \mathrm{~T} / \mathrm{d}$ with 195 centres. CPCB has framed the compliance report as projected in Table 3 (CPCB, 2020).

Table 3. State-wise generation of COVID-19 BMW and disposal facilities 


\begin{tabular}{|c|c|c|c|c|c|c|c|}
\hline \multirow[t]{3}{*}{ S.No } & \multirow{3}{*}{$\begin{array}{l}\text { Name of } \\
\text { State/UT }\end{array}$} & \multirow{3}{*}{$\begin{array}{l}\text { COVID- } \\
19 \\
\text { BMW ( } \\
\text { in } \\
\text { TPD) }\end{array}$} & \multicolumn{4}{|c|}{ Details of Facilities } & \multirow{3}{*}{$\begin{array}{l}\text { Adequacy of an existing } \\
\text { treatment facility }\end{array}$} \\
\hline & & & \multirow[t]{2}{*}{$\begin{array}{l}\text { No. of } \\
\text { CBWTFs } \\
\text { engaged }\end{array}$} & \multicolumn{2}{|c|}{$\begin{array}{l}\text { Captive } \\
\text { facilities }\end{array}$} & $\begin{array}{l}\text { Deep } \\
\text { burial } \\
\text { pits }\end{array}$ & \\
\hline & & & & $\mathbf{Y}$ & $\mathbf{N}$ & $\mathbf{Y} \quad \mathbf{N}$ & \\
\hline 1 & A \& $\mathbf{N}$ Islands & 0.014 & 0 & & & & $\begin{array}{l}\text { Adequate with captive } \\
\text { facilities. }\end{array}$ \\
\hline 2 & $\begin{array}{l}\text { Andhra } \\
\text { Pradesh }\end{array}$ & 5.516 & 11 & & & & Adequate. \\
\hline 3 & $\begin{array}{l}\text { Arunachal } \\
\text { Pradesh }\end{array}$ & 0.112 & 0 & & & & Depends on burial pits. \\
\hline 4 & Assam & 0.946 & 1 & & & & $\begin{array}{l}\text { The capacity of the Common } \\
\text { Biomedical Waste Treatment } \\
\text { Facility (CBWTF) is not } \\
\text { adequate and one facility } \\
\text { cannot cater to the needs of } \\
\text { the entire state. Need to depend } \\
\text { on the captive facilities and } \\
\text { burial pits. }\end{array}$ \\
\hline 5 & Bihar & 0.228 & 4 & & & & $\begin{array}{l}80 \% \text { of the incinerator capacity } \\
\text { is utilized. Need to ensure } \\
\text { proper segregation technique. }\end{array}$ \\
\hline 6 & Chandigarh & 0.995 & 1 & & & & Adequate \\
\hline 7 & Chhattisgarh & 0.373 & 2 & & & & $\begin{array}{l}\text { The adequate capacity of } \\
\text { CBWTFs. Details of more } \\
\text { disposal options are not } \\
\text { provided. }\end{array}$ \\
\hline 8 & $\begin{array}{l}\text { Dadra \& } \\
\text { Nagar Haveli }\end{array}$ & 0.015 & 1 & & & & $\begin{array}{l}\text { Adequate. Waste is being } \\
\text { disposed of through CBWTF at } \\
\text { Surat, Gujarat. }\end{array}$ \\
\hline 9 & Delhi & 11.114 & 2 & & & & $\begin{array}{l}70 \% \text { of the existing capacities } \\
\text { of two incinerators are utilized. } \\
\text { Need to ensure proper } \\
\text { segregation. }\end{array}$ \\
\hline 10 & Goa & 0.027 & 0 & & & & $\begin{array}{l}\text { No CBWTF. Need to depend on } \\
\text { captive facilities and burial } \\
\text { pits. }\end{array}$ \\
\hline 11 & Gujarat & 11.693 & 20 & & & & Adequate. \\
\hline 12 & Haryana & 2.511 & 11 & & & & Adequate. \\
\hline 13 & $\begin{array}{l}\text { Himachal } \\
\text { Pradesh }\end{array}$ & 0.127 & 2 & & & & $\begin{array}{l}\text { Adequate capacity with } \\
\text { incinerators. two CBWTFs may } \\
\text { not be adequate to cover the } \\
\text { entire state. }\end{array}$ \\
\hline
\end{tabular}




$14 \quad \begin{gathered}\text { Jammu and } \\ \text { Kashmir }\end{gathered} \quad 0.357 \quad 2$

15 Jharkhand

2

16 Karnataka

2.8

25

17 Kerala

4.71

1
Two CBWTFs may not be adequate to cover the entire state. Need to depend on captive facilities and burial pits.

Compiled information was not available and hence adequacy could not be assessed.

Adequate.

All COVID biomedical waste was sent to CBWTF. The capacity of CBWTF is not adequate for the total BMW. Hence captive facilities need to be operated.

18 Lakshadweep $0.01 \quad 2$

2 Adequate. May use 2 captive incinerators in 2 islands and deep burial pits in the rest of the islands.

$19 \begin{array}{llll}\text { Madhya } \\ \text { Pradesh }\end{array} \quad 7.486 \quad 11 \quad$ Adequate.

$20 \quad$ Maharashtra $\quad 17.494 \quad 29$

$21 \quad$ Manipur $\quad 0.171 \quad 1$

22 Meghalaya $\quad 0.17 \quad 1$

Adequate. Standby

arrangement is made with

Treatment, Storage, and

Disposal Facilities (TSDFs) in

Mumbai, Pune, and Nagpur

cities.

Adequate. A however single facility may not cater to the entire state.

Adequate information is not available. The existing incinerator cannot dispose of the entire waste generated from the state.

$23 \quad$ Mizoram $\quad 0.14 \quad 0$

$24 \quad$ Nagaland $\quad 0.12 \quad 0$

25 Odisha $\quad 1.062 \quad 5$

26 Puducherry $0.621 \quad 2$

27 Punjab

1.6
Adequate information is not available.

Adequate information is not available.

$79 \%$ of the common incinerator's capacity is utilized. Need to ensure the proper segregation of waste.
Adequate.

Adequate.

Punjab 1.6




\begin{tabular}{|c|c|c|c|c|}
\hline 28 & Rajasthan & $5 . .9$ & 8 & $\begin{array}{l}88 \% \text { of the common } \\
\text { incinerator's capacity is } \\
\text { utilized. Need to ensure proper } \\
\text { segregation and identify the } \\
\text { alternate facilities }\end{array}$ \\
\hline 29 & Sikkim & 0.2 & 0 & $\begin{array}{l}\text { Adequate information is not } \\
\text { available. }\end{array}$ \\
\hline 30 & Tamil Nadu & 10.41 & 8 & $\begin{array}{l}91 \% \text { of incinerator capacity is } \\
\text { utilized. Eleven Centres need to } \\
\text { ensure proper segregation and } \\
\text { identify alternate } \\
\text { incinerators/disposal options }\end{array}$ \\
\hline 31 & Telan & 0.41 & 11 & Adequate \\
\hline 32 & Tripura & $0 . .015$ & 1 & $\begin{array}{l}71 \% \text { of incinerator capacity is } \\
\text { utilized }\end{array}$ \\
\hline 33 & Uttar Pradesh & 0.53 & 2 & $\begin{array}{l}92 \% \text { of Incinerator capacity is } \\
\text { utilized. Only } 2 \text { incinerators } \\
\text { may not be adequate to cater } \\
\text { entire state area. Need to } \\
\text { depend on deep burial } \\
\text { disposal. }\end{array}$ \\
\hline 34 & Uttarakhand & 7 & 18 & Adequate. \\
\hline 35 & West Bengal & 6.5 & 6 & Adequate. \\
\hline Total & 101 & 195 & & \\
\hline
\end{tabular}

\section{Potential Disposal Of Bmw During Covid-19}

Out of all the techniques, the incinerator has emerged as one of the most efficient and reliable methods to dispose of tons of biomedical waste safely. The incineration method has many benefits, it is affordable, easy to handle, operate, maintain, and is also easily transported. Using the incineration process, waste is treated to reduce the volume by $90 \%$ and the weight by $70 \%$. Bearing in mind the quantum method for rapid disposal of biomedical waste (Jaber et al., 2021). The main advantage of the incineration method is the release of heavy metals such as $\mathrm{Hg}, \mathrm{Pb}, \mathrm{Cd}, \mathrm{Cr}, \mathrm{Cu}, \mathrm{Zn}, \mathrm{Ni}$, etc., as by-products during the combustion processes (Liu et al., 2012). This study intended to highlight the existing BMW incineration plant capacity, particularly during the COVID-19 pandemic timeline.

\subsection{Quantitative and Qualitative disposal of BMW using incineration technologies}

The hazardous waste generated during the pandemic comprised mainly of huge PPE kits and other single-use medical care equipment. It was reported that there was a monthly increase of $40 \%$ in the production of PPE kits after the spread of COVID-19 (WHO, 2020b). As seen from Figure 4, the waste will 
be segregated in the yellow category of Biomedical waste (Y-BMW) and is a predominant category of waste that can be disposed of through the use of incineration technologies. The sudden increase in waste generation due to COVID-19 has challenged waste management systems all over the world. During the peak of the virus in China, waste generation increased six fold in tons per day whereas in the USA it increases from 5MT/y to $300 \mathrm{MT} / \mathrm{y}$; facemasks alone resulted in 66k tons of Y-BMW. From 20th Jan 2020 to 30th May 2020, the Republic of South Korea generated around 2000 T of Y-BMW. The quantity of Y-BMW out of the Total BMW generated for seven states in India was estimated as $50.44 \%$ as per the CPCB report (Thind et al., 2021). Incineration is noted to be the preferred method for Y-BMW disposal in India.

\subsection{Impact of BMW on the environment and human health}

Clinical waste incinerators liberate many toxins such as particular matter (PM), fly ash debris, heavy metals such as arsenic, chromium, copper, mercury, and lead (Valerio, 2010). The emissions include corrosive gases like hydrogen chloride, hydrogen fluoride, sulfur dioxide, nitrogen dioxide, carbon monoxide, and particulates. Scientists from different nations have conducted a variety of tests encompassing the diagnosis, disinfectant, cleaning, testing, and the incineration processes and observed the release of highly poisonous gases that can cause serious diseases such as cancer (WHO, 2016), lead to reproductive and development problems, and damages the immune system. They also observed that these components were just toxic but they were also flammable, highly reactive, and genotoxic (Sarkodie \& Owusu, 2021). The continuous exposure to and the inhalation of such harmful gases can result in cancer. The occurrence of carcinogenic and non-carcinogenic health risks, associated with the exposure of adults and children in India during the incineration of total Y-BMW was studied by Parteek Singh (Thind et al., 2021).

\section{Ways To Control Bmw During Covid-19}

Due to the onslaught of the COVID-19 pandemic, there is an unprecedented increase in the composition and the volume of the waste product which has led to a critical situation in different states with $70 \%$ and more capacity utilization of existing incinerators. The following are some suggestions for enhancement in BMW management in developing countries like India.

- Improvement of the current bio-waste management policies, plans, and guidelines

- Occupational health and safety assessments

- Management of household infectious waste

- Installation of proper incinerators and related infrastructure

Policymakers and governmental bodies should come forward to revamp the existing policies and guidelines by considering the present pandemic situation. A regional network must be established and baselines must be framed for knowledge-sharing and Concentrated BMW management. This will be of immense help to developing countries like India in dealing not only with the current situation but also 
equipping themselves to tackle the challenges of BMW with other upcoming pandemics shortly (Shammi et al., 2021).

\section{Conclusion}

The implementation of a systematically planned and smoothly functioning BMW management system that oversees the collection, handling, segregation, storage, processing, disinfection, and disposal facilities will ensure that there are no adverse impacts on society, the ecosystem, or the environment. BMW treatment plays a predominant role in maintaining a clean and healthy society which could be affected by illegal dumping of potentially infectious and hazardous waste in open public spaces. The pandemic crisis has shaken the entire world including developed countries which continue to struggle with managing the proper disposal of BMW. Most developing countries, India included, are not tapping the full potential of disposal techniques, particularly the incinerator. A technical cum operational improvement of incineration technologies is necessary for the sustainable management of biomedical waste generated from COVID treatment in the country. The generation of biomedical waste is continuously increasing the number of COVID-19 cases due to the need for and usage of disposable masks, gloves, and PPE kits all of which are mandatory precautions to guard against the contagious nature of the virus. The proper disposable of these medical wastes becomes a huge problem. Safe and sustainable management of the BMW generated by the healthcare system in compliance with the prevailing laws is, therefore, the need of the hour. Hence, the incinerator plays an indispensable role in safeguarding human lives as well as protecting the environment by sustainably managing BMW. Incineration is an appropriate disposal method that is adopted for the easy processing of Y-BMW which forms a significant part of the total BMW. Many biotech industries and healthcare centres lack the technology and know-how to correctly segregate waste before incineration proper segregation of BMW and modern biomedical waste incineration units must necessarily be installed on-site in all medical centres. The government must take steps to stop the menace of open disposal and improper dumping of toxic biomedical waste through continuous monitoring and active regulatory bodies. Strict laws, policies, and regulations must be framed to penalize and control the menace of unsafe discard of hazardous BMW in public areas. Frequent awareness programs, education, and proper training programs on the segregation at source based on color code and scientific disposal of BMW must be provided. It must ensure that the biomedical waste is safely handled during this infectious pandemic period as it can pose a serious health threat to healthcare workers, patients, public and lead to environmental degradation. To effectively tackle the corona pandemic situation, the entire BMW management system has to be properly streamlined and disposal methodologies must be optimized sustainably for preserving the health of all humanity while also promoting a clean and green environment.

\section{Nomenclature}

SARS-Cov-1 - Severe Acute Respiratory Syndrome Coronavirus 1.

SARS-Cov-2 - Severe Acute Respiratory Syndrome Coronavirus 2. 
COVID-19 - Coronavirus Disease 2019

BMW - Biomedical Waste

CPCB - Central Pollution Control Board

WHO - World Health Organization

BAT - Best Available Technology

MERS - Middle East Respiratory Syndrome

PPE - Personal Protective Equipment

RDF - Refuse Derived Fuel

AllMS - All India Institute of Medical Science

MCF - Medical Care Facility

$D_{n}$ - Daily face mask uses

P - Population

Up - Urban Population (\%)

FMAR - (Facemask acceptance rate)

FMGP - Assumption that each person in the general population use one face mask each day

\section{Declarations}

\section{Acknowledgment}

Dr. D. Sakthivadivel and Mr. C.K. Pon Pavithran, acknowledge the Department of Science Technology (SEED Division) - STI Hub, Government of India, for funding the project vide Project No. DST/SEED/TSP/STI/2020/243.

Availability of data and materials: The experimental data sets supporting the results of this article are included within the article.

Funding: Not applicable.

Ethics approval and consent to participate: Not applicable.

Consent for publication: Not applicable. 
Conflict of interests: The authors declare that they have no competing interests.

\section{Declaration of competing interest}

The authors declare that they have no known competing financial interests or personal relationships that could have appeared to influence the work reported in this paper.

\section{Author's contribution}

Duraiswamy Sakthivadivel and Sung Chul Kim - These are the corresponding authors who equally contributed in the preparation of the Manuscript. Conceptualization, Methodology, Resources, Formal analysis

Pon Pavithiran, Arpit Bhatia, Anmol Verma, Nehal Ratnesh Shah, Pratyush Prakash- Data Collection, Writing - original draft preparation, review and editing, Formal analysis.

Shanmugarajan Vigneswaran and Poongavanam GaneshKumar - Writing - original draft preparation, review and editing, Supervision and investigation.

\section{References}

1. Arora, N. K., Pillai, R. N., Maheshwari, M., Arya, S., Gupta, R. Das, Chaturvedi, S., \& Goswami, K. (2014). Bio-medical waste management: Situational analysis \& predictors of performances in 25 districts across 20 Indian states. Indian Journal of Medical Research, 139(January), 141-153.

2. Behera, B. C. (2021). Challenges in handling COVID-19 waste and its management mechanism: A Review. Environmental Nanotechnology, Monitoring and Management, 15(February). https://doi.org/10.1016/j.enmm.2021.100432

3. Chand, S., Shastry, C. S., Hiremath, S., Joel, J. J., Krishnabhat, C. H., \& Mateti, U. V. (2021). Updates on biomedical waste management during COVID-19: The Indian scenario. Clinical Epidemiology and Global Health, 11(March), 100715. https://doi.org/10.1016/j.cegh.2021.100715

4. CPCB. (2020). Guidelines for Handling, Treatment and Disposal of Waste Generated during Treatment/Diagnosis/ Quarantine of COVID-19 Patients. Central Pollution Control Board. https://cpcb.nic.in/uploads/Projects/Bio-Medical-Waste/BMW-GUIDELINES-COVID_1.pdf

5. CPCB. (2021). COVID-19 Waste Management. Central Pollution Control Board. https://cpcb.nic.in/covid-waste-management/

6. CSE India. (2021). 46 percent increase in COVID-19 biomedical waste generation in India in AprilMay 2021, says CSE's new statistical analysis. Centre for Science and Environment. https://www.cseindia.org/46-per-cent-increase-in-covid-19-biomedical-waste-generation-in-india-inapril-may-2021-10849 
7. Das, A. K., Islam, M. N., Billah, M. M., \& Sarker, A. (2021). COVID-19 pandemic and healthcare solid waste management strategy - A mini-review. Science of the Total Environment, 778, 146220. https://doi.org/10.1016/j.scitotenv.2021.146220

8. Datta, P., Mohi, G., \& Chander, J. (2018). Biomedical waste management in India: Critical appraisal. Journal of Laboratory Physicians, 10(01), 006-014. https://doi.org/10.4103/jlp.jlp_89_17

9. Dharmaraj, Selvakumar, Veeramuthu Ashokkumar, Sneha Hariharan, Akila Manibharathi, Pau Loke Show, Cheng Tung Chong, and Chawalit Ngamcharussrivichai. "The COVID-19 pandemic face mask waste: a blooming threat to the marine environment." Chemosphere 272 (2021): 129601.

10. Fischer, R. J., Morris, D. H., Doremalen, N. Van, Sarchette, S., Matson, M. J., Bushmaker, T., Yinda, C. K., Seifert, S. N., Gamble, A., Williamson, B. N., Judson, S. D., Wit, E. De, Lloyd-Smith, J. O., \& Munster, V. J. (2020). Effectiveness of N95 respirator decontamination and reuse against SARS-CoV-2 Virus. Emerging Infectious Diseases, 26(9), 2253-2255. https://doi.org/10.3201/eid2609.201524

11. Gold, N. A., \& Avva, U. (2018). Alcohol Sanitizer. StatPearls, 1-8.

http://www.ncbi.nlm.nih.gov/pubmed/30020626

12. Hossain, I., Medicine, S., \& Mullick, A. R. (2020). Pandemic COVID-19 and Biomedical Waste Handling: A Review Study. May.

13. Jaber, S., Aljawad, A. A., Prisecaru, T., \& Pop, E. (2021). A theoretical study on the mass input and output and energy of the biomedical waste incinerator. E3S Web of Conferences, 286, 02016. https://doi.org/10.1051/e3sconf/202128602016

14. Kitajima, M., Ahmed, W., Bibby, K., Carducci, A., Gerba, C. P., Hamilton, K. A., Haramoto, E., \& Rose, J. B. (2020). SARS-CoV-2 in wastewater: State of the knowledge and research needs. Science of the Total Environment, 739, 139076. https://doi.org/10.1016/j.scitotenv.2020.139076

15. Liu, H., Kong, S., Liu, Y., \& Zeng, H. (2012). Pollution Control Technologies of Dioxins in Municipal Solid Waste Incinerator. Procedia Environmental Sciences, 16, 661-668. https://doi.org/10.1016/j.proenv.2012.10.091

16. Nishiura, H., Linton, N. M., \& Akhmetzhanov, A. R. (2020). Initial Cluster of Novel Coronavirus (2019$\mathrm{nCoV}$ ) Infections in Wuhan, China Is Consistent with Substantial Human-to-Human Transmission. Journal of Clinical Medicine, 9(2), 488. https://doi.org/10.3390/jcm9020488

17. Peng, J., Wu, X., Wang, R., Li, C., Zhang, Q., \& Wei, D. (2020). Medical waste management practice during the 2019-2020 novel coronavirus pandemic: Experience in a general hospital. American Journal of Infection Control, 48(8), 918-921. https://doi.org/10.1016/j.ajic.2020.05.035

18. Reddy, K., Renuka, N., Kumari, S. and Bux, F., 2021. Algae-mediated processes for the treatment of antiretroviral drugs in wastewater: prospects and challenges. Chemosphere, p.130674.

19. Richter, A., Ng, K. T. W., Vu, H. L., \& Kabir, G. (2021). Identification of behaviour patterns in waste collection and disposal during the first wave of COVID-19 in Regina, Saskatchewan, Canada. Journal of Environmental Management, 290(February), 112663.

https://doi.org/10.1016/j.jenvman.2021.112663 
20. Salkin, I. . (2004). Review of Health Impacts from Microbiological Hazards in Health-Care Wastes. Geneva: World Health Organization. 1-3.

21. Sangkham, S. (2020). Face mask and medical waste disposal during the novel COVID-19 pandemic in Asia. Case Studies in Chemical and Environmental Engineering, 2(September), 100052. https://doi.org/10.1016/j.cscee.2020.100052

22. Sarkodie, S. A., \& Owusu, P. A. (2021). Impact of COVID-19 pandemic on waste management. Environment, Development and Sustainability, 23(5), 7951-7960. https://doi.org/10.1007/s10668020-00956-y

23. Seetharam, S. (2009). Hepatitis B outbreak in Gujarat: a wake-up call. Indian Journal of Medical Ethics, 6(3), 120-121. https://doi.org/10.20529/ijme.2009.042

24. Shammi, M., Behal, A., \& Tareq, S. M. (2021). The Escalating Biomedical Waste Management to Control the Environmental Transmission of COVID-19 Pandemic: A Perspective from Two South Asian Countries. Environmental Science and Technology, 55(7), 4087-4093. https://doi.org/10.1021/acs.est.0c05117

25. Singh, A. (2020). COVID-19 and Biomedical Waste Management. Social and Political Research Foundation. https://sprf.in/covid-19-and-biomedical-waste-management/

26. Suman, R., Javaid, M., Haleem, A., Vaishya, R., Bahl, S., \& Nandan, D. (2020). Sustainability of Coronavirus on Different Surfaces. Journal of Clinical and Experimental Hepatology, 10(4), 386-390. https://doi.org/10.1016/j.jceh.2020.04.020

27. Tagorti, G. and Kaya, B., 2021. Genotoxic effect of microplastics and COVID-19: The hidden threat. Chemosphere, p.131898.

28. Thakur, A. K., Sathyamurthy, R., Velraj, R., Lynch, I., Saidur, R., Pandey, A. K., Sharshir, S. W., Kabeel, A. E., Hwang, J. Y., \& GaneshKumar, P. (2021). Secondary transmission of SARS-CoV-2 through wastewater: Concerns and tactics for treatment to effectively control the pandemic. Journal of Environmental Management, 290(April). https://doi.org/10.1016/j.jenvman.2021.112668

29. Thind, P. S., Sareen, A., Singh, D. D., Singh, S., \& John, S. (2021). Compromising situation of India's bio-medical waste incineration units during pandemic outbreak of COVID-19: Associated environmental-health impacts and mitigation measures. Environmental Pollution, 276, 116621. https://doi.org/10.1016/j.envpol.2021.116621

30. Tripathi, A., Tyagi, V. K., Vivekanand, V., Bose, P., \& Suthar, S. (2020). Challenges, opportunities and progress in solid waste management during COVID-19 pandemic. Case Studies in Chemical and Environmental Engineering, 2(November), 100060. https://doi.org/10.1016/j.cscee.2020.100060

31. Valerio, F. (2010). Environmental impacts of post-consumer material managements: Recycling, biological treatments, incineration. Waste Management, 30(11), 2354-2361. https://doi.org/10.1016/j.wasman.2010.05.014

32. Walkinshaw, E. (2011). Medical waste-management practices vary across Canada. CMAJ: Canadian Medical Association Journal = Journal de l'Association Medicale Canadienne, 183(18), 1307-1308. https://doi.org/10.1503/cmaj.109-4032 
33. WHO. (2016). Dioxins and their effects on human health. WHO. https://www.who.int/newsroom/fact-sheets/detail/dioxins-and-their-effects-on-human-health

34. WHO. (2018). Health-care waste. WHO. https://www.who.int/news-room/fact-sheets/detail/healthcare-waste

35. WHO. (2020a). Infection Prevention and Control for the safe management of a dead body in the context of COVID-19. Journal of Hospital Infection, 104(3), 246-251.

36. WHO. (2020b). Shortage of personal protective equipment endangering health workers worldwide. WHO. https://www.who.int/news/item/03-03-2020-shortage-of-personal-protective-equipmentendangering-health-workers-worldwide $\% 0 \mathrm{~A} \% 0 \mathrm{~A}$

37. WHO. (2021a). COVID-19 vaccines. WHO. https://www.who.int/emergencies/diseases/novelcoronavirus-2019/covid-19-vaccines

38. WHO. (2021b). WHO Coronavirus (COVID-19) Dashboard. WHO. https://covid19.who.int/

39. Worldometer. (2021). COVID-19 CORONAVIRUS PANDEMIC. Worldometer. https://www.worldometers.info/coronavirus/

40. Zhang, D., Ling, H., Huang, X., Li, J., Li, W., Yi, C., Zhang, T., Jiang, Y., He, Y., Deng, S., Zhang, X., Wang, X., Liu, Y., Li, G., \& Qu, J. (2020). Potential spreading risks and disinfection challenges of medical wastewater by the presence of Severe Acute Respiratory Syndrome Coronavirus 2 (SARS-CoV-2) viral RNA in septic tanks of Fangcang Hospital. Science of the Total Environment, 741, 140445. https://doi.org/10.1016/j.scitotenv.2020.140445

\section{Figures}




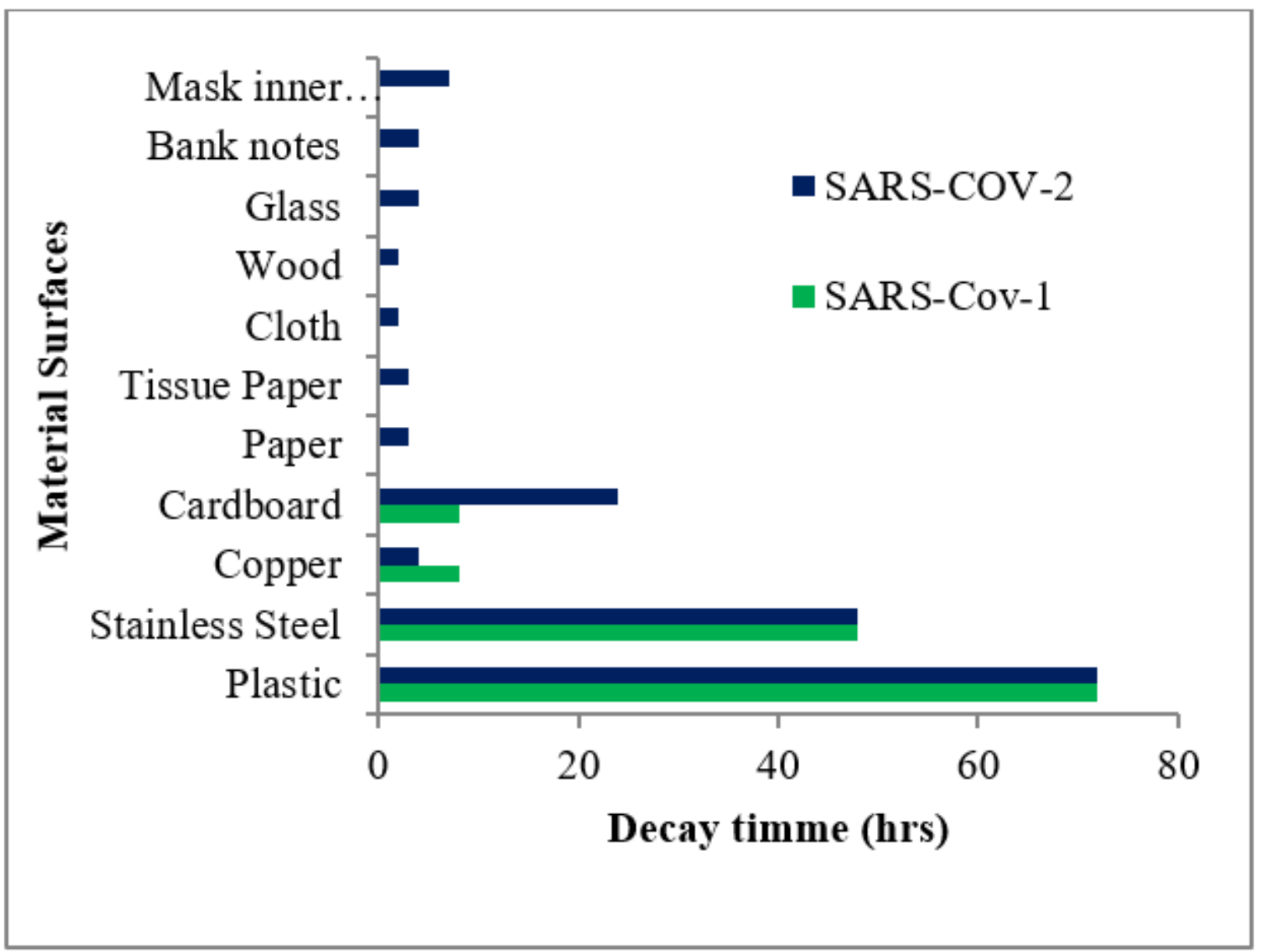

Figure 1

Decay time of the coronavirus (Suman et al., 2020; Tripathi et al., 2020) (in hours) 


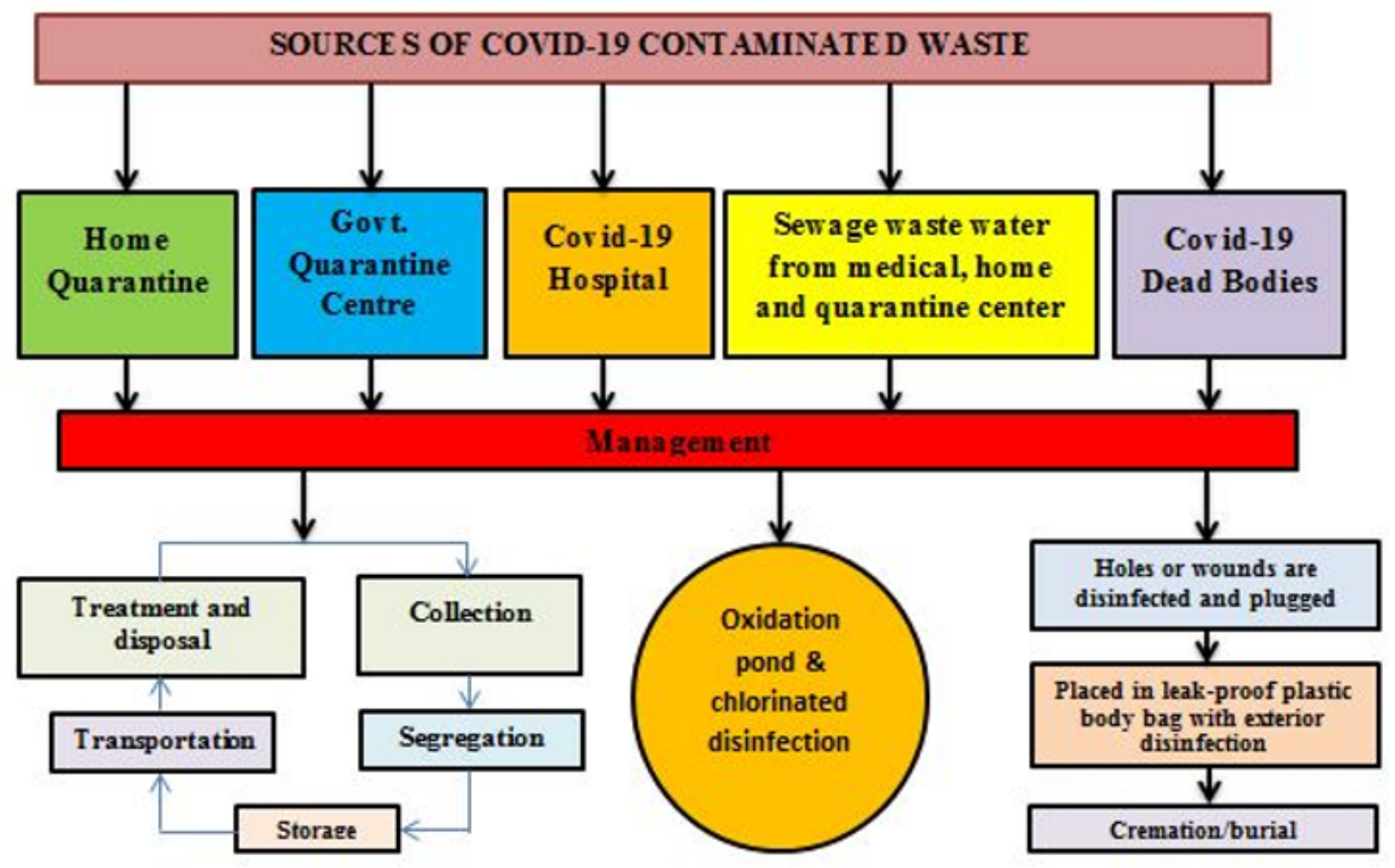

Figure 2

Overview of healthcare solid waste management during COVID-19 pandemic (Behera, 2021) 


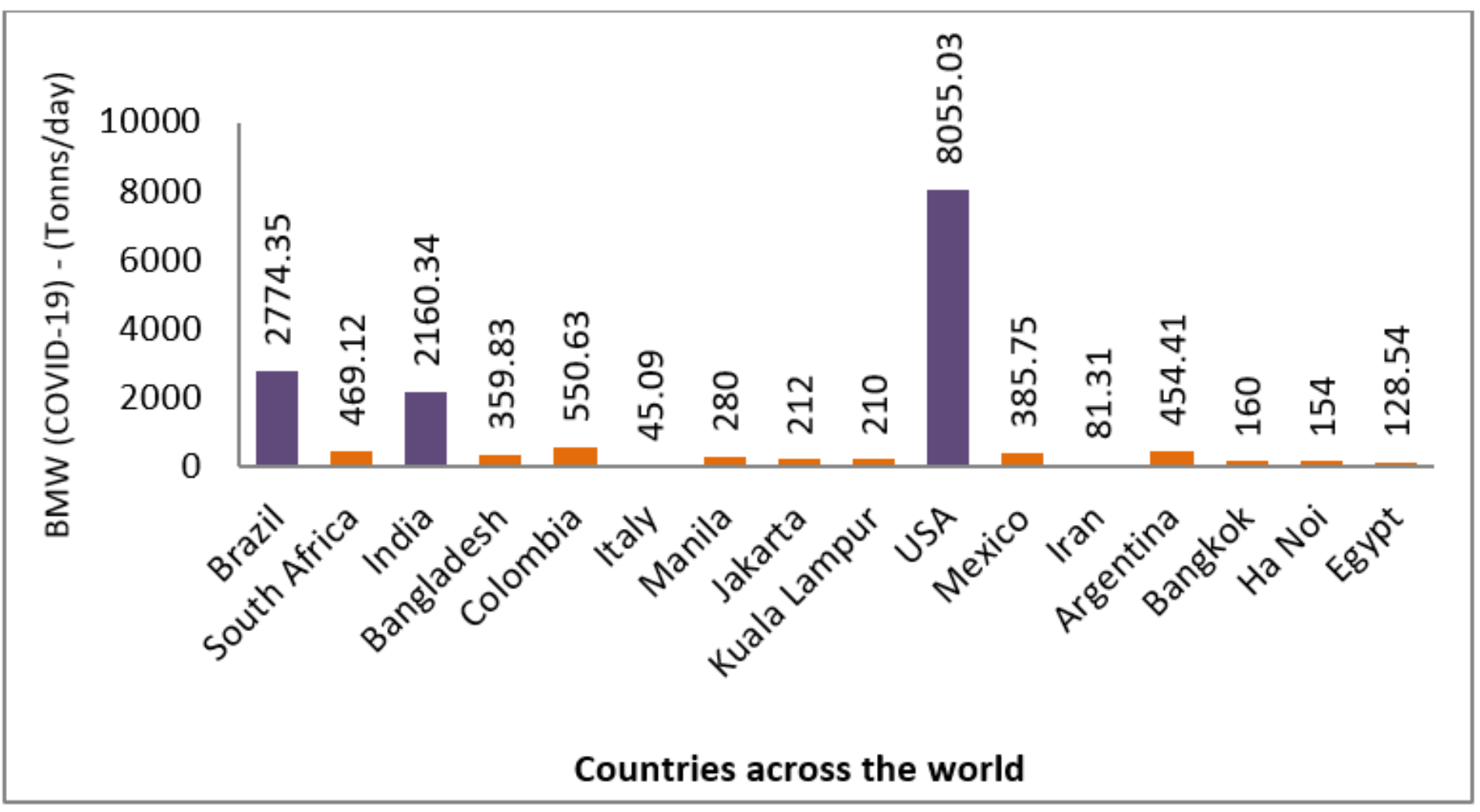

Figure 3

COVID-19 BMW is produced by different countries (Sangkham, 2020).
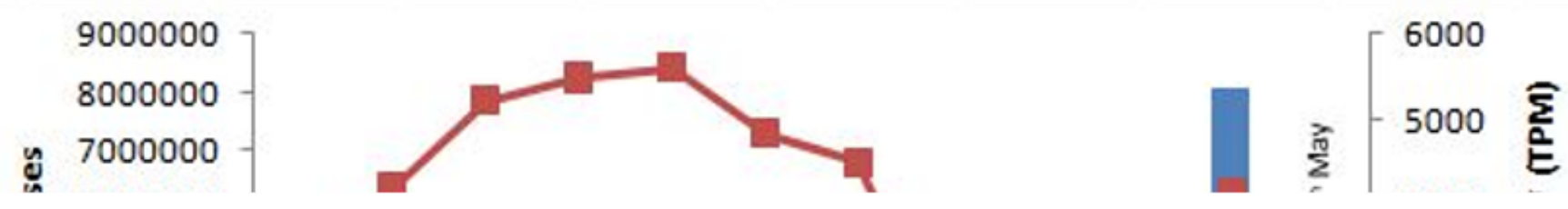
Figure 4

Variation in the generation of BMW corresponds to COVID-19 cases.

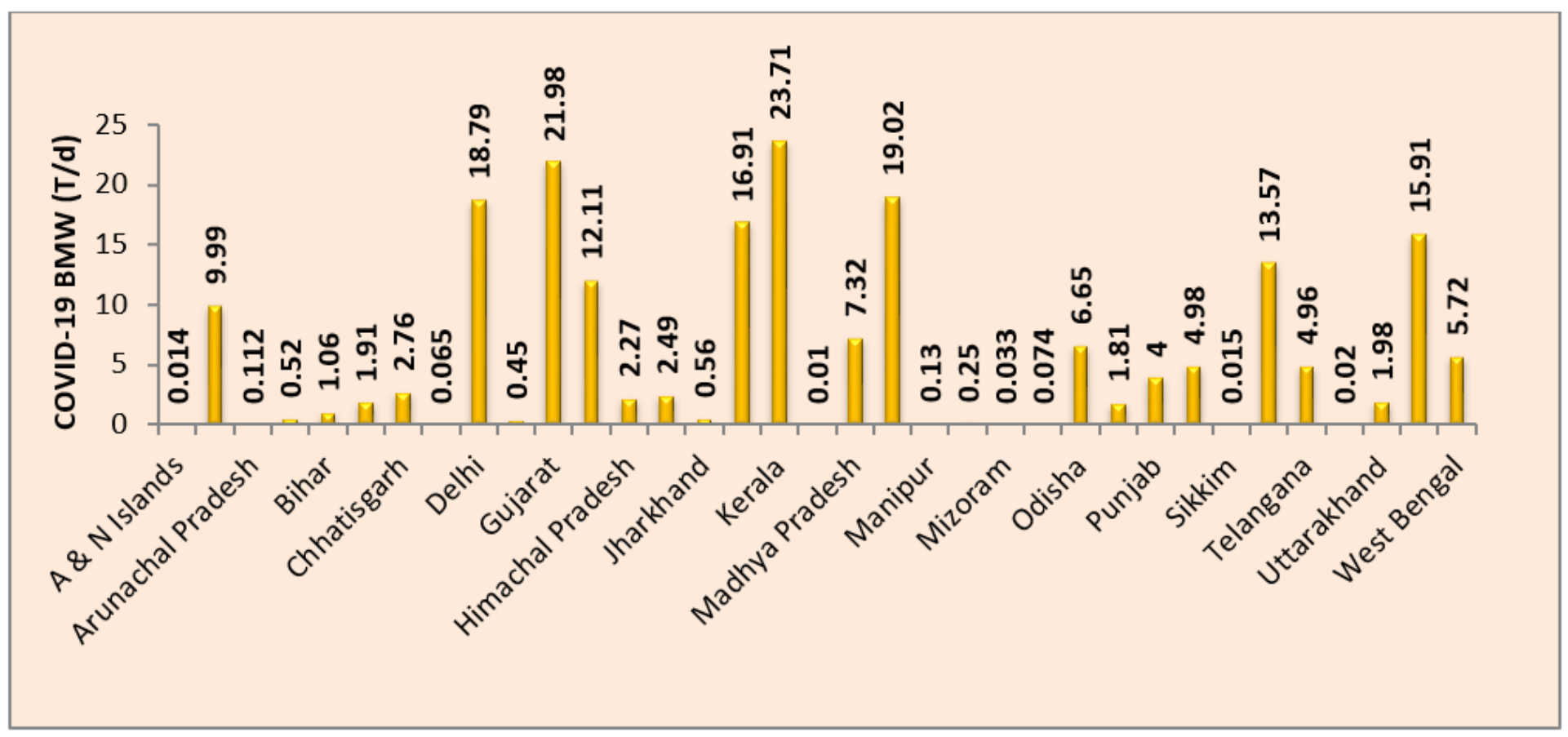

Figure 5

State-wise generation of BMW (tons/day) during the COVID-19 pandemic. 


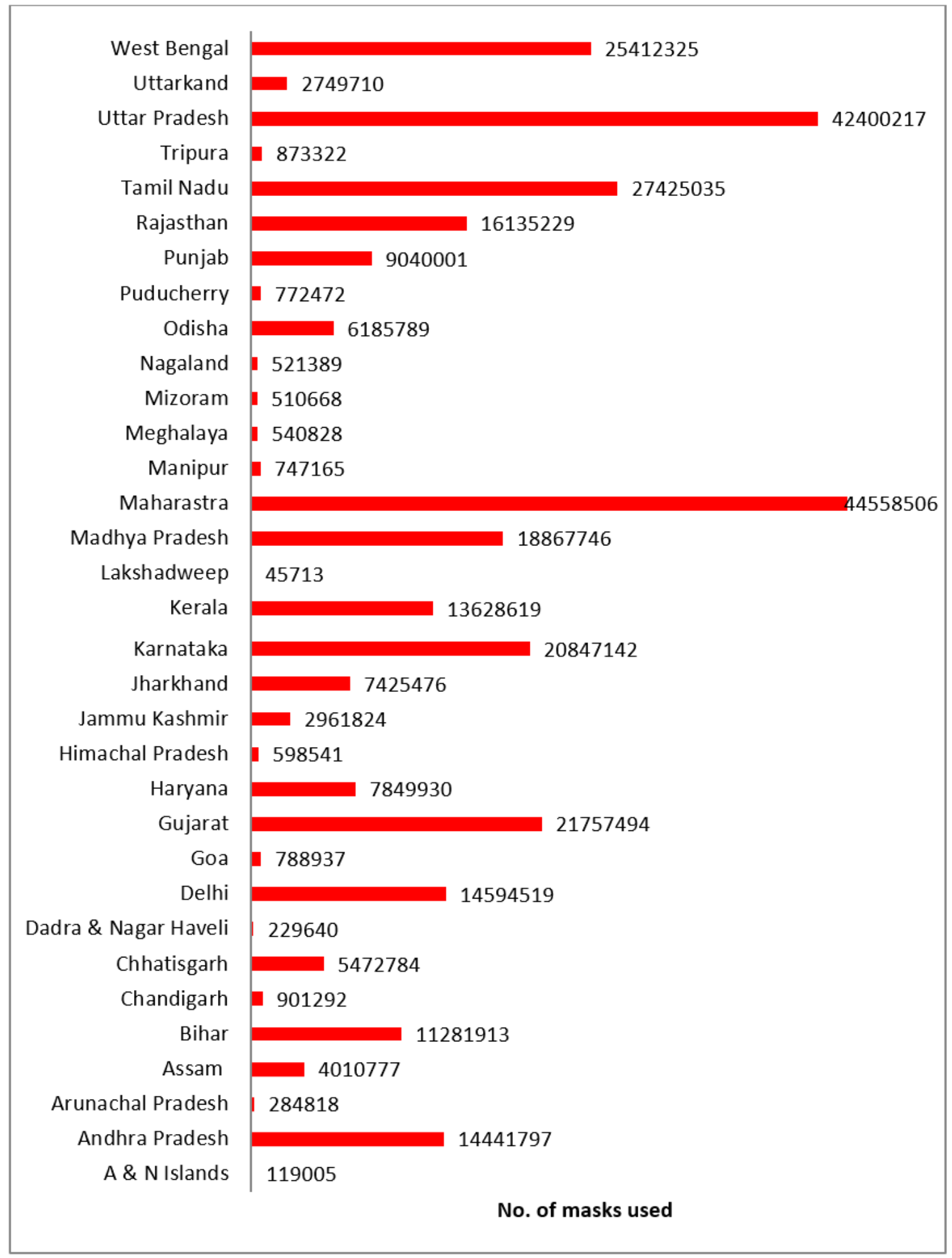

\section{Figure 6}

Estimated daily facemask usage in India concerning confirmed COVID-19 cases. 
Sharp Waste Products, Non-Toxic Chemical Waste Products, Recyclable Waste Products, NonBiodegradable Waste
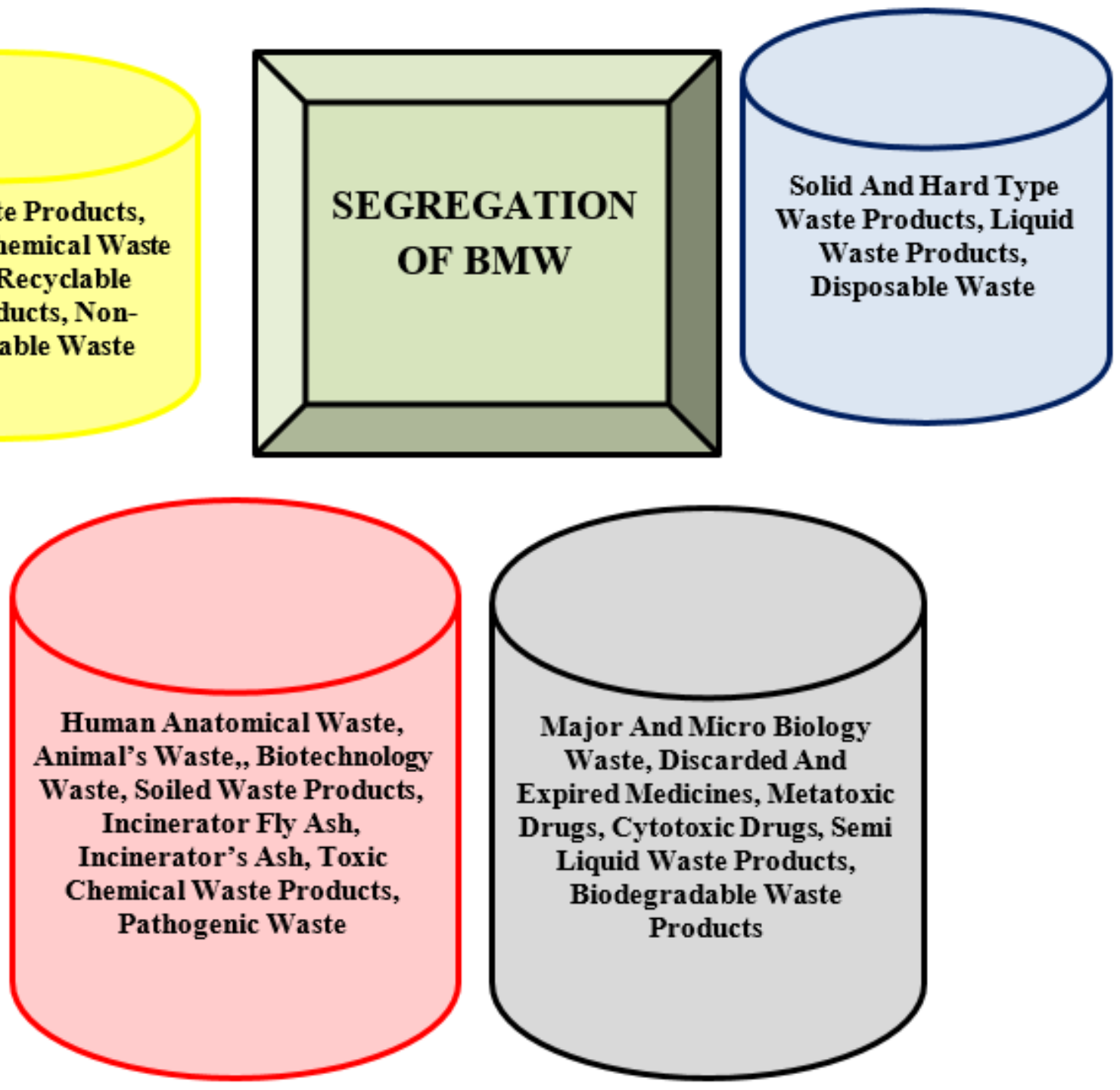

Figure 7

Segregation of BMW in respective color-coded containers 